CHAPTER 11

\title{
Peter without Paul: Aspects of the Primordial Role of Simon Peter in an Early Christian Context
}

\author{
Annewies van den Hoek
}

In the last quarter of the fourth century bishop Epiphanius of Salamis, the staunch defender of Christian faith and tireless campaigner against heresy whether actual or presumed - made the following statement in his Panarion:

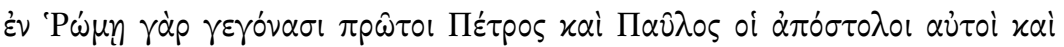

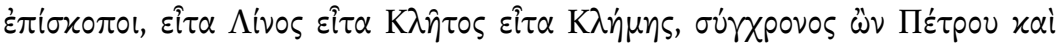

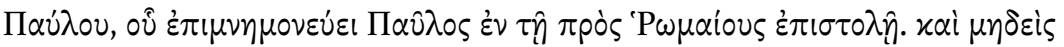

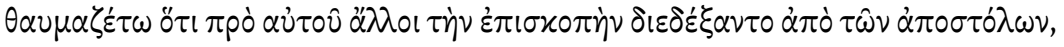

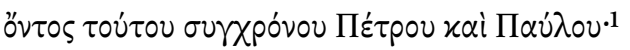

For in Rome first the apostles Peter and Paul themselves were also bishops, then Linus, then Cletus, then Clement, who was a contemporary of Peter and Paul, whom Paul mentions in the Letter to the Romans. And no one should be surprised that others before him received the episcopacy from the apostles, though he was a contemporary of Peter and Paul.

By the fourth century the apostles Peter and Paul had stellar reputations and were established as founders of the Roman church and anchors of its prestige. Rome had a long tradition of being anchored in figures who were perceived as a duality, first of all, the twins Romulus and Remus, who are best known as the mythological founders of the eternal city. ${ }^{2}$ Though of Greek origin, Castor and Pollux, also known in Latin as the Gemini or Castores, are another couple solidly anchoring the traditions of Rome. ${ }^{3}$ It should not come as a surprise therefore that the two most prominent apostles were cast in this dual role as well. The reference to both of them, however, as bishops of Rome is rather unusual. Epiphanius repeated the idea several times, mainly as an argument in defense of the apostolic succession of church leaders in Rome. Of course, the

1 Epiphanius, Pan. 27.6.2-3.

2 See Humphries' contribution to this volume.

3 See Van den Hoek (2017). 
appeal to authority and legitimacy could already be heard some two hundred years earlier by authors such as Irenaeus of Lyons and Clement of Alexandria,

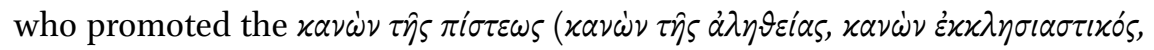
and there are more elaborate terms as well). ${ }^{4}$ The Latin equivalent was regula fidei or regula ueritatis, ${ }^{5}$ a rule for measuring faith and faithful allegiance to the Christian cause, which for Irenaeus and Clement primarily consisted of the agreement between the Septuagint and the nascent New Testament as an instrument for the right interpretation of scripture. In addition, the $x a v \dot{\nu} \nu \tau \hat{\jmath} \varsigma$ $\pi i \sigma \tau \varepsilon \omega \varsigma$ was a rhetorical device in a most competitive religious environment; a measuring rod that was employed polemically against related groups, who under the same Christian banner did not seem to adhere to the same rulings and thus were denied legitimacy.

Although uncommon, Epiphanius may not have been alone in naming both Peter and Paul bishops of Rome. Another important theologian and historian two or three generations his senior could have inspired his statement. Eusebius of Caesarea starts his first book of the Ecclesiastical History in the very first sentence covering a full page that the clear purpose of his work was to write about the succession of the sacred apostles, thus reconstructing Christianity from its origins. ${ }^{6}$ Subsequently in book three, when dealing with the episcopal successions in Alexandria in the time of Nerva and Trajan, Eusebius drops a few names from Rome:

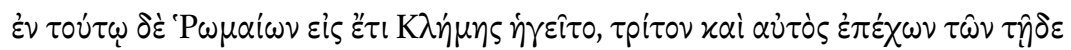

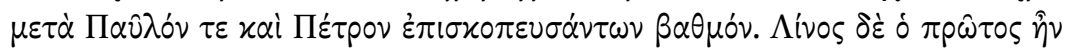

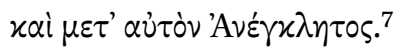

At that time, Clement was still in charge of the Romans - also he being three steps back from those there who after Paul and Peter exercised the office of episkopos. Linus was the first and after him came Anacletus.

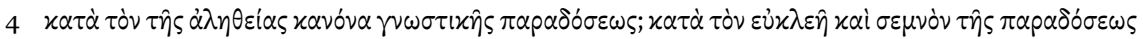
xavóva, see Van den Hoek \& Mondésert (2001) 6o, note 1.

5 Tertullian, Praescr. 12; 13; 26; Pud. 8; and passim.

6 Eusebius, $H E$ 1.1.1.

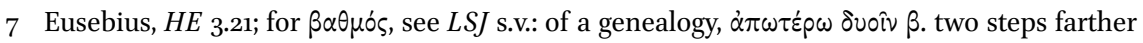
back, i.e. farther back than one's grandfather. The translation of Rufinus reads: qua tempestate in urbe Roma Clemens quoque tertius post Paulum et Petrum pontificatum tenebat (At that time in the city of Rome also Clemens held the episcopacy in third place after Paul and Peter). 
It is not totally clear from Eusebius' Greek whether or not Paul and Peter are included in the $\tau \hat{\omega} \nu$... $\dot{\varepsilon} \pi l \sigma \kappa o \pi \varepsilon v \sigma \alpha \dot{\nu} \tau \omega \nu$, but Epiphanius may have understood it this way. However, there seems to be little substance to the idea that Paul ever was named a bishop, let alone, bishop of Rome. ${ }^{8}$

After the close pairing of Peter and Paul in early sources, it is striking to see that the two often appear as individuals in the fourth century, with the emphasis usually on Peter. Just to give a few examples: when Constantine ordered new churches to be built in Rome, the one on Vatican hill was much larger and more splendid than the one for Paul on Via Ostiense. The latter seems to have been a rather small enterprise, cramped into a narrow space between two roads. ${ }^{9}$ Only in the late fourth century did the emperors close one of the roads constricting the space for Paul's church and build a virtual replica of St. Peter's, with five aisles and a transept.

Not only in large church building activities but also in smaller-scale figurative arts a similar preference for Peter appears to have existed..$^{10}$ Christian sarcophagi give this impression strongly. Although Paul is certainly not absent, Peter is much more frequently represented; his image can be seen not only on representations of his arrest and martyrdom (as with Paul) but in a variety of scenes, such as the miracle of the rock with soldiers drinking and the denial scene with the rooster, to mention just a few. ${ }^{11}$ When Peter performs the water miracle and strikes the rock, he appears as the successor of Moses; this visual tradition has its base in popular stories, such as later versions of the Acts of Peter. ${ }^{12}$ For Paul such biblical pre-figurations do not seem have been developed by artists, writers, or story-tellers. Admittedly, there were miraculous stories in the reception history of Paul's life as there were in the narratives of Peter. The nexus of Peter and Moses, however, has a different theological flavor and points perhaps at a re-enactment of old biblical stories in a new Christian environment, comparable to something like the Praeconium Paschale in a

8 Irenaeus simply writes that "Peter and Paul in Rome are evangelizing and founding the

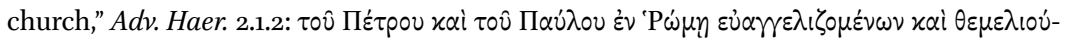

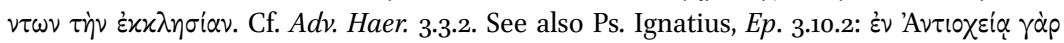

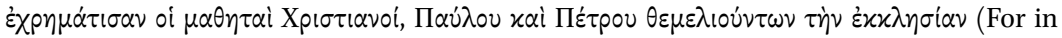
Antioch the disciples were called "Christians," when Paul and Peter were founding the church).

9 See Eastman (2011) 24-7.

10 See Dresken-Weiland (2011) 126-152, with extensive bibliography and her contribution in this volume.

11 See Provoost (2011). Peter Lampe also has given statistics on the frequency and variety of Petrine scenes on Roman sarcophagi; Lampe (2015) 273-317, esp. 294-303, and Table 3, $316-17$.

See Jensen (1992) 395-398; Jensen (2019). 
liturgical context. Images of Peter as Moses are also common in Roman catacomb painting - and it is not always easy to distinguish whether Moses or Peter was intended. ${ }^{13}$ Peter Lampe remarks that 'Peter can be depicted without Paul, but the apostle from Tarsus almost exclusively appears together with Peter. ${ }^{14}$ Moreover, when they are depicted together the honor of receiving the scroll of the law goes to Peter.

In yet a different art form, the more down-to-earth material of clay, we also see the apostle Peter as a clearly defined type. In contrast to sarcophagi and catacomb paintings, the objects are not very elite; they consist of small ceramic lamps from North Africa. Peter's image dominates on lamps, although the two apostles also appear together on other ceramics from this area, as on platters and bowls. I should add that this form of art can be easily replicated since it is mold made, and the lamps are particularly abundant. ${ }^{15}$ As with the sarcophagi and catacomb paintings, one could reinforce these observations with numerical data, which make clear that Peter as a stand-alone is much more frequent. ${ }^{16}$

What should we make of this? Why is Peter more popular than Paul on a variety of materials in the fourth century? Scholars engaged in the early Christian visual arts have pointed out that the upper classes associated themselves more comfortably with Peter. Referring to sarcophagi on which Peter's posture and gestures echo those of philosophers, Peter Lampe writes: 'Thus, the upperclass Roman owners of the sarcophagi like to associate themselves with Peter. Peter was learned like a philosopher and endowed with power and authority.'17 Jutta Dresken-Weiland states that: 'the sequence of images of Peter is a peculiarity of the sarcophagi and can be explained by the will and the self-concept of the commissioners, who very often were from the upper class of society.'18 Others suggest that there may have been a difference between the visual and literary sources in this respect. Peter would have taken up more prominence

\footnotetext{
13 Bisconti (2000) 44-5.

14 Lampe (2015) 290.

15 Meg Armstrong has made a thesaurus of applied motives on African Red Slip ware, which is still useful for tabulation, although rendered somewhat obsolete by recent discoveries: Armstrong (1993); for images, see Van den Hoek and Herrmann (2013) 324; 542.

16 On sarcophagi and catacomb painting Provoost counts about four times as many images in the cycle of Peter as in the cycle of Paul; Provoost (2011) 1.138 and 141.

17 Lampe (2015) 303.

18 Dresken-Weiland (2011), 63-78, in the English summary preceding the article; see also 72: 'Die besondere Verehrung des Petrus lässt sich durch das Selbstverständnis der stadtrömischen Oberschicht-Christen erklären; es war ihnen wohl angelegen, dass sie sich als Angehörige der stadtrömischen Eliten Bilder des Mannes auf ihre Gräber setzten, der als Gründer der römischen Gemeinde und als Nachfolger Christi ebenfalls in einer führenden Rolle verehrt wurde.'
} 
in the visuals and Paul is more cited in texts, particularly in poetry. ${ }^{19}$ From a fourth-century perspective, these observations seem legitimate, but whether such associations were as self-evident as some authors suggest remains to be seen. Thus, my initial question remains: why does the weight fall on Peter and not on Paul? Are there perhaps earlier indications to justify such a preference? Religious traditions usually do not come suddenly out of the blue.

Historically speaking, or rather based on literary evidence from earlier times, the connection of Paul with Rome can more easily be established than that of Peter. Paul's Letter to the Romans shows the apostle's interest in writing to fellow-Christians in Rome and the desire to visit the imperial capital. ${ }^{20}$ His Letter to the Philippians may have been written from Rome and, if that is the case, gives interesting additional information about contentious relationships. ${ }^{21}$ In the book of Acts, which is dedicated to the aftermath of Jesus' life, death, and resurrection, both Peter and Paul play major roles, but there is a strange transition halfway through when the stories about Peter and other apostles fade out and the focus is redirected to the mission of Paul and his entourage. The last chapters elaborate on hostilities endured by Paul in Jerusalem, his trial in Caesarea, and his travel to and subsequent stay in Rome as a prisoner. We would have loved to hear more, particularly about where Paul ended up: did he go further to the West, or perhaps back to the East, or was he found guilty and executed in the eternal city itself? The story is open-ended and we can only speculate about the reasons. ${ }^{22}$

In contrast, Peter does not seem to have had much connection with Rome in the earliest sources. He started out as a fisherman from the Galilee, and, generally speaking, fishermen were not particularly high on the social scale of Roman society. They were often made fun of in both text and image. ${ }^{23}$ As already noted, Peter figures in the first part of canonical Acts in his key role as a witness to the resurrection after which he fades away. Geographically Peter's activity is limited to the traditional areas of the Jesus movement: Jerusalem, Judaea, Samaria, and the Galilee. Peter does go beyond this area when he starts a mission among gentiles in Antioch, where he also encounters Paul. Further information about Peter comes from the letters of Paul and from the canonical Gospels. In Galatians, Peter had the famous altercation with Paul, an episode that continues to play an important role in the reception history

\footnotetext{
19 Dijkstra (2016) 403; see also Sessa (2012).

$20 \quad$ Rom. 1.8-15.

21 For the arguments for Rome (versus Ephesus or Caesarea) as the least problematic, see Bockmuehl (1998) 32 .

22 On traditions of Paul's death, see Marguerat (2015) 305-32; Di Berardino (2015) 521-32.

23 See Laubscher (1982); Bekker-Nielsen (2002); Lytle (2012).
} 
of that text and of the relationship between the two apostles. ${ }^{24}$ In the four canonical Gospels Peter gained a venerable reputation, though with a variety of connotations. ${ }^{25}$ In most accounts, he is the preeminent disciple of Jesus who functions as a spokesperson and represents the group of twelve. ${ }^{26} \mathrm{He}$ shows strengths and weaknesses: his confession about Jesus as the Messiah is powerful and influential, but it is countered by his failure and denial. This contrast between his outstanding role as a disciple and his abject failing will also remain an issue throughout later theological debates.

Whatever the theological differences may have been, toward the early second century Peter and Paul gradually appear as a team. This tendency of unification may have started already in the book of Acts. Although Luke portrays them in sequence rather than together, they are the two main players in his narrative. Other examples of this tendency are pseudo-epigraphic texts under the name of Peter, such as the letters of Peter. Helmut Koester viewed these letters as written in the Pauline tradition but under Peter's name to give them more authority and to unify the apostles and their presumed constituencies. ${ }^{27}$ In 1 Clement 5 both Peter and Paul are mentioned together as apostles and martyrs; ${ }^{28}$ throughout this paragraph the language seems martyr-related with a connection to Rome by association. ${ }^{29}$ The Letter to the Romans of Ignatius provides a similar testimony with an implied connection to Rome. ${ }^{30}$ There is no need to repeat all the key passages and arguments here - they are well-known

24 Gal. 2, 11-14; also Van den Hoek and Herrmann (2013) 301-26.

25 See Bockmuehl (2012) 19-33. Gnilka (2002) 142-78.

26 See Lampe, Thümmel, and Hardt (2011).

27 Koester (1980) 294. For texts documenting opposition to Paul, see Luedemann (1989).

28 1Clement 5 . See also Still (2015) 163.

29 Pace Zwierlein (2010) 30; in my opinion, a cluster of typical "martyr" terms can be seen in

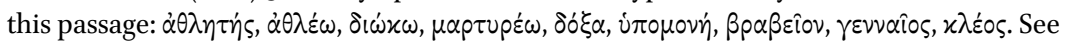
also Zwierlein (2011) 444-67, and Zwierlein (2013).

30 Ignatius, Rom. 4.3; cf. also John 21.18-19. Di Berardino (2015) 521, notes that no firm date has been established for Ignatius' lifetime, which ranges from 110 to ca. 170. In 171-172

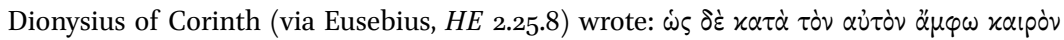

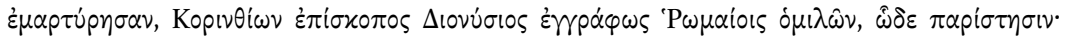

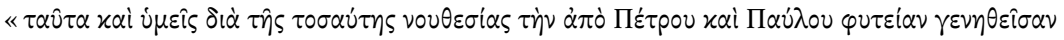

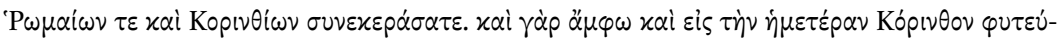

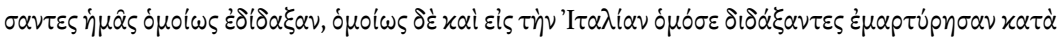

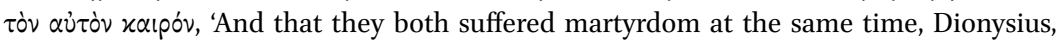
bishop of the Corinthians, conversing with the Romans, says in a written statement as follows: 'By such a great admonition you united the planting done by Peter and of Paul at Rome and Corinth. For both planted and likewise taught us in our Corinth, and they taught together in like manner in Italy, and suffered martyrdom at the same time'. 
and well-studied. ${ }^{31}$ They make clear that very early a tradition about the concordia apostolorum exists with a special connection to Rome. ${ }^{32}$ The question then arises, why does the weight fall on Peter and not on Paul in Christian art of the fourth century (and onwards)?

Some evidence appears in the later second and the third centuries that can be read in the light of the later imbalance in their relationship at Rome. Archaeological information comes from the via Appia just outside Rome at the funerary complex under the church of S. Sebastiano, also known as in memoria apostolorum. ${ }^{33}$ Already early in the fourth century Eusebius made mention of this location in his Church History:

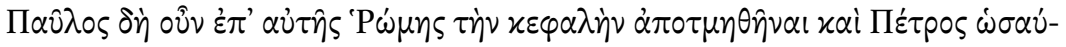

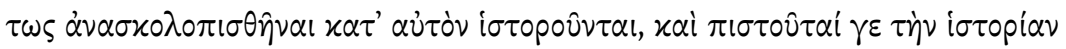

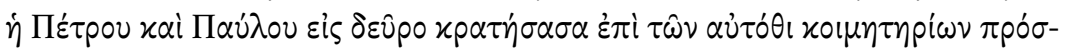

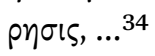

It is reported that Paul was beheaded in Rome itself and that likewise Peter was crucified during his (Nero's) reign, and the designation "of Peter and Paul," which is still current at the cemeteries there confirms the report ...

'Still' is referring to Eusebius' own day, and 'there' means Rome; the sentence then continues with the well-known reference to Gaius and the quotation about the tropaeum of each apostle - which do not concern us here. The area of commemoration at the cemeteries has long been located right under the center of the later church of San Sebastiano. Reconstruction shows that this structure, which is traditionally called the triclia, was an open courtyard with a kind of portico on one side. The walls of this loggia were covered with hundreds of graffiti, invoking the names of Peter and Paul, partly in Latin, partly in Greek, a few in Latin with Greek script; some are intact but most are very fragmentary. ${ }^{35}$ They were evidently connected with funerary banquets in the honor of both the saints and the deceased. Richard Krautheimer remarks that: 'were its walls not covered with invocations to the apostles (one dated to 260)

31 See the recent studies of Zwierlein on Peter in Rome above and the scholarly responses they evoked.

32 It doesn't make much difference for my argument here whether one dates 1 Clement to c. 100 or 120.

33 See Friedrichs' contribution to this volume.

34 Eusebius, $H E$ 2.25.5.

35 Snyder (1985) 141-45. 


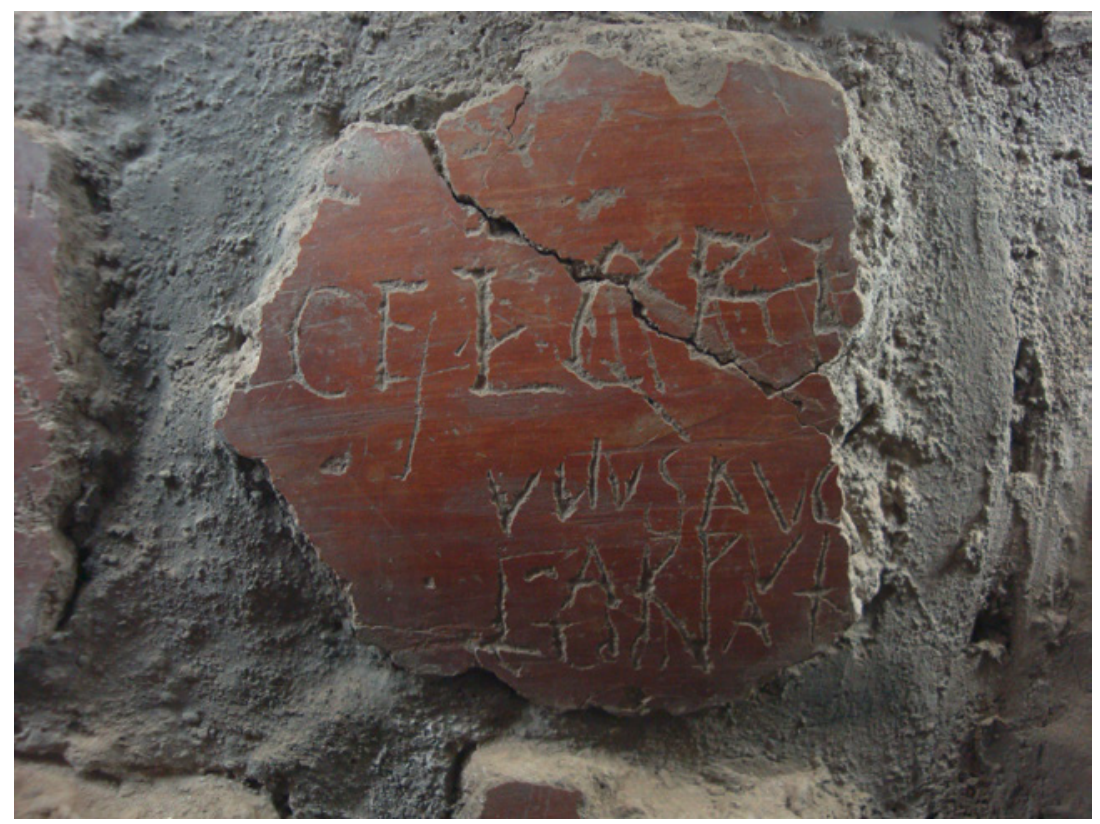

FIGURE 11.1 Graffito with possible consular date (26o CE) from the Triclia, ICVR, V 12935, EDB 26596

and with records of feasts in their honor, the loggia might be the pergola of an ordinary osteria'.36 One of the graffiti may give the consular date, to which Krautheimer refers: (fig. 11.1)

.... Celeri ...
vidus aug.....
saccul ..........
et Donat ...

which was read by Robert Marichal as: Celeri[nus] / V Idus Aug[ustas] / Saccul[ari II] / et Donat [o II co(n)s(ulibus)], Celerinus on the 9th of August with Saecularis and Donatus as consuls (both for the 2nd time)."38

$36 \quad$ Krautheimer (1965/1975) 34-5.

37 Styger (1918) Tav. 11. Toynbee and Ward Perkins (1956) 268. $A E$ 1954,54; $A E$ 1956,236; $A E$ 1957,45.

38 Marichal, $A E$ 1954,54. The reading is still contested; for different readings by Guarducci and Ferrua, see Felle (2012) 478, and note 6. 
We also know through other ancient sources that from 258 onwards a festival commemorating Peter and Paul was celebrated at this location. ${ }^{39}$ The site began to be used in the 250 and came to an end after the construction of the church of S. Sebastiano, originally the Basilica Apostolorum, somewhere in the first half of the fourth century. ${ }^{40} \mathrm{My}$ interest in these intercessions, in which Peter and Paul are addressed so frequently, is primarily because of the sequence in which their names occur; who came first: was it Peter and Paul or Paul and Peter? For this I looked at the inscriptions as they are published in the fifth volume of the Inscriptiones Christianae Urbis Romae and as they appear on the Bari database.$^{41}$ Of the more than three hundred graffiti that were discovered not all could be reconstructed; whenever a reconstruction was certain with either the name of Peter or Paul or both, even in fragmentary form (... et Petre, or Paule et ...), I would include it in my tabulation. In this way, I counted 85 Latin and 28 Greek inscriptions in which both apostles were addressed, so 113 graffiti in total. In Latin Peter appears first 50 times, while Paul appears first only 35 times; in Greek Paul appears first 16 times, and Peter appears first 12 times. (fig. 11.2) Thus, it appears that for the Latin speakers there is an inclination to name Peter first, but for the Greek speakers there is a slight preference for putting Paul in first position - and I want to stress again how amazing it is to have this prime documentary information from pre-Constantinian times still available. It is virtually a public opinion poll. ${ }^{42}$

Several textual sources from pre-Constantinian times show the interplay between these preferences. Obviously, the apocryphal Acts of Peter, in which Peter plays a prominent role, come to mind; ${ }^{43}$ they are joined by a wide range of texts with the name of Peter attached to them, among them the later Pseudo-Clementines. ${ }^{44}$ These novelistic narratives as such do not form a valid argument for the precedence of one apostle over the other, since the Acts of Peter parallel the Acts of Paul and other such traditions; in fact, there are many interconnections between the Petrine and Pauline apocryphal Acts that are not easy to explain.

39 For the date and further bibliography, see Di Berardino (2015), 521-32, esp. $5^{24}$.

$40 \quad$ See also Carandini (2013) 145-51.

41 Ferrua, ICUR V, 12907-13090. For the Epigraphic Database Bari, see http://www.edb .uniba.it/.

42 I am aware of the statistical problem based on small numbers.

43 Lipsius-Bonnet (1891-1903). Vouaux (1922) 398-466. For further bibliography, see Bremmer (1998) 200-2.

44 Rehm (1953); Irmscher $\left(1967^{2}\right)$; Paschke $\left(199^{3}\right)$. Paschke (1965); Paschke (1994²). For further bibliography, see Bremmer (2010) 306-25. 


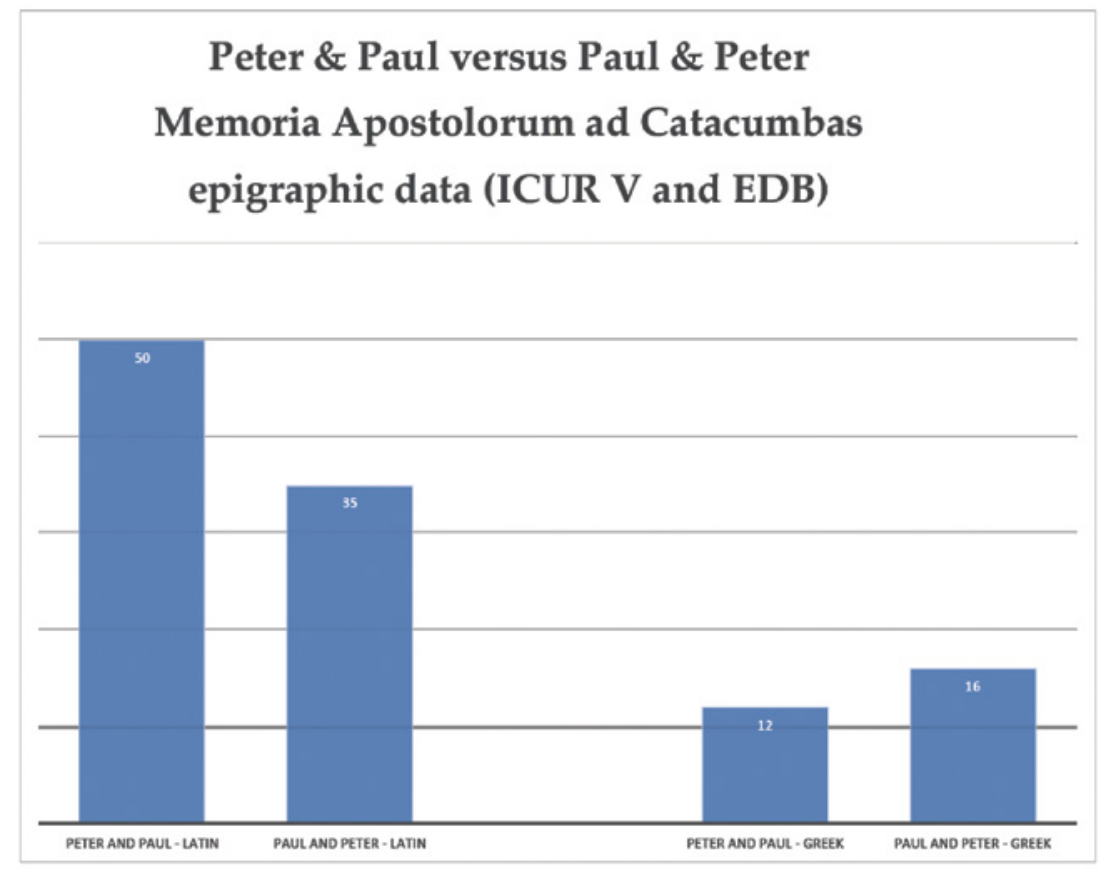

FIGURE 11.2 Tabulation of the sequence of the apostolic names on graffiti of the Triclia

There are some features in the Acts of Peter, however, that can shed light on the issue of apostolic preferences and balance. ${ }^{45}$ The work has a complex history; it was originally composed in Greek, probably toward the end of the second century (180-190) but had a wide dissemination with many oriental versions as well. Its largest surviving fragment is in Latin, known from the Codex Vercellensis $158 .{ }^{46}$ The place of origin is not known, perhaps Rome, perhaps not. Obviously, Peter is the principle character of the narrative, but strangely enough the first three paragraphs of the Actus Vercellenses begin with Paul and his departure from Rome, and in the last chapters Paul appears again. The main narrative of the Acts is about a contest in working miracles between Peter and Simon Magus, a proto-heretical figure. It is mostly set in Rome but starts in Jerusalem and concludes with the inglorious failure of Simon, followed by Peter's martyrdom. Scholars have noticed that the references to Paul in the beginning and at the end of the Actus Vercellenses are not well integrated into

45 For a general survey of Peter's role in non-canonical traditions, see Foster (2015) 222-62. For the relationships between Peter, Paul, and Simon, see also Bockmuehl (2010) 94-113.

46 From where they are also called the Actus Vercellenses. 
the text, causing discontinuities and even contradictions. ${ }^{47}$ This suggests that they are interpolations - supposedly the work of a redactor who drew from the Pauline epistles and had an interest in expressing harmony between the two apostles in an otherwise Petrine context. ${ }^{48}$

When we have a Greek and a Latin version available, as in the story of the martyrdom of Peter and Paul, there are examples in which the Latin passage gives more prominence to Peter than the Greek version does, as we saw in the graffiti. In an article on Peter and Paul in Rome, Gahbauer included some of the instances ${ }^{49}$ and it may suffice here to quote one example: in the Martyrium Petri and Pauli 44 during the fictitious interrogation by the emperor Nero, the Greek text reads:

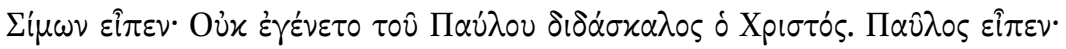

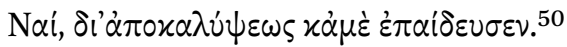

Simon (Magus) said: 'Christ was not the teacher of Paul.' Paul said: 'certainly, he instructed also me through his revelation.'

The Latin equivalent of the Passio Sanctorum Apostolorum Petri et Pauli 44 renders the situation as follows:

Simon dixit: Pauli Christus magister non fuit. Paulus dixit: qui Petrum praesens docuit, ipse me per revelationem instruxit. ${ }^{51}$

Simon (Magus) said: 'Christ was not the teacher of Paul.' Paul said: 'the one who taught Peter in person, instructed me too through his revelation.'

Peter's position is even more prominent in the Pseudo-Clementine literature; there great emphasis is placed on Peter as founder of the church ${ }^{52}$ - though these texts are hard to date (roughly from the third century onwards), but the tendency is interesting nevertheless. The Ps. Clementine Homilies are preceded by the so-called Letter of Peter to James. They may date to the fourth century but supposedly contain earlier materials. The work is written from a

47 Thomas (2003) 22-3.

48 This also happens in the martyrdom of Peter, in which Paul suddenly appears.

49 Gahbauer (2001) 155-67.

5o Lipsius-Bonnet (1891-1903) 156, ll. 19-21.

$5^{1} \quad$ Lipsius-Bonnet (1891-1903) 157, ll. 18-20.

$5^{2}$ See, for example, Rufinus' version of the Epistula ad Iacobum 1.2. 
Jewish-Christian perspective with a strong defense of the law of Moses. One of the most striking passages reads as follows:

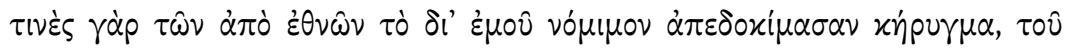

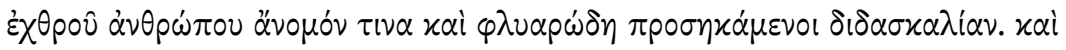

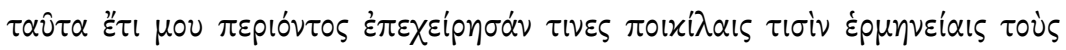

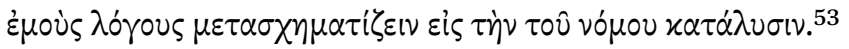

For some from the gentiles have rejected my preaching according to the law, admitting some lawless and nonsensical teaching of the man who is my enemy. And some tried these things while I am still around to transform my words by manifold interpretations, for the dissolution of the law.

It is not certain who the proclaimed enemy is, but if it is aimed at the apostle Paul, this text would be overtly anti-Pauline and go well beyond the hints seen in the sources above. ${ }^{54}$

In contrast with the preferences displayed in these novelistic and popular texts, writings of theologians of the late second and early third centuries usually bring up Peter and Paul together, as strong and unifying emblems of faith against heresy, as guarantors of apostolic succession, and ultimately of the authority of the Roman church. However, these texts should not obscure the historical reality that there must have been many different Christian groups in second century Rome (as in other cities for that matter), each with their own alliances and often competing with one another for turf. ${ }^{55}$ The problem is that history is mostly written by the parties that ultimately prevailed - and the few sources available may well reflect this phenomenon.

We will first hear from Irenaeus, a theologian and later bishop of Lyons in Gaul, who migrated from Asia Minor to the West shortly after the middle of the second century and who also spent time in Rome. Irenaeus makes his point loud and clear: ${ }^{56}$

53 Epistula Petri, 2.3-4. Irmscher, Paschke, and Rehm (1969) 1-2.

54 Gerd Luedemann refers to other anti-Pauline tendencies in the Pseudo-Clementines; see Luedemann (1989) 169-196. In general, also Porter (2005); Gray (2016).

55 For Christian groups in the second century, see the work of Lampe (2003). For the dangers to Christians in opposing other philosophical schools to the point of death threats, see Baarda (2017). Tjitze Baarda refers to a certain Crescens, who had threatened Tatian's teacher Justin and may have been involved in Justin's demise, see Tatian, Oration 19; cf. Eusebius, $H E$ 4.16; Jerome, Vir. ill. 23.

$5^{6}$ Christoph Markschies makes the point that Irenaeus' emphasis on the institutional traditions and the authority of the bishops came from threats to these communities from free teachers with a different set of views and scriptures; Markschies (2015) 234-5. 
Sed quoniam ualde longum est in hoc tali uolumine omnium Ecclesiarum enumerare successiones, maximae et antiquissimae et omnibus cognitae, a gloriosissimis duobus apostolis Petro et Paulo Romae fundatae et constitutae Ecclesiae, eam quam habet ab apostolis traditionem et adnuntiatam hominibus fidem per successiones episcoporum peruenientem usque ad nos indicantes, confundimus omnes eos qui quoquo modo, uel per sibi placentiam uel uanam gloriam uel per caecitatem et sententiam malam, praeterquam oportet colligunt: ad hanc enim Ecclesiam propter potentiorem principalitatem necesse est omnem conuenire Ecclesiam, hoc est eos qui sunt undique fideles, in qua semper ab his qui sunt undique conseruata est ea quae est ab apostolis traditio. ${ }^{57}$

But since it would be too long in a volume like this to enumerate the successions of all the churches, we (will speak about) the church that is the greatest, most ancient and known to all, founded and established by the two most glorious apostles Peter and Paul at Rome; while showing that the tradition that it has from the apostles and the faith that was announced to the people coming down through the successions of bishops even to our time, we put to shame all those who in any way for their own pleasure or vain glory or blindness or bad judgment assemble illegitimately. For it is necessary that every church - that means the faithful everywhere agrees with this church, because of its more powerful primary place, (this church) in which the tradition that comes from the apostles has always been preserved by those who are from everywhere.

A few generations later similar views on the founding fathers and their legacy can be heard from Tertullian. Like Irenaeus, Tertullian states that Christians in North Africa derive their authority from the church in Rome. He lays this out in De Praescriptione Haereticorum:

... si autem Italiae adiaces, habes Romam unde nobis quoque auctoritas praesto est. Ista quam felix ecclesia cui totam doctrinam apostoli cum sanguine suo profunderunt, ubi Petrus passioni dominicae adaequatur, ubi Paulus Iohannis exitu coronatur ... ${ }^{58}$

57 Irenaeus, Adv. Haer. 3.3.2.

$5^{8}$ Praescr. 36 . Tertullian was also the first to state that both Peter and Paul were victims under persecution of Nero, Scorpiace 15. 
... if you are near Italy, you have Rome, from where we also derive our authority. How blessed is that church on which the apostles poured forth their whole doctrine along with their blood, where Peter endures the same passion as the Lord, where Paul is being crowned in death like John.

In this polemical discussion about apostolic authority, Tertullian puts more flesh on the bones, i.e. additional names on the apostolic succession:

Hoc enim modo ecclesiae apostolicae census suos deferunt, sicut Smyrnaeorum ecclesia Polycarpum ab Iohanne collocatum refert, sicut Romanorum Clementem a Petro ordinatum est. Perinde utique et ceterae exhibent quos ab apostolis in episcopatum constitutos apostolici seminis traduces habeant. ${ }^{59}$

For in this way apostolic churches convey their origin, just as the church of Smyrna reports that Polycarp was placed there by John, and as the Roman church asserts that Clement was ordained by Peter. Anyway, in like manner also the other churches present those who were appointed by the apostles to the episcopacy and hold the shoots of the apostolic seed.

When it comes to episcopal ordination and succession, Tertullian singles out Peter as the one who ordained Clement and omits Paul. ${ }^{60}$ Irenaeus, however, includes Paul in this process of ecclesiastical organization as well as in the foundation of the church:

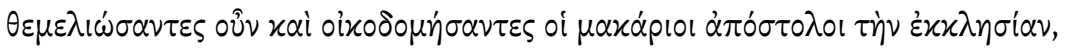

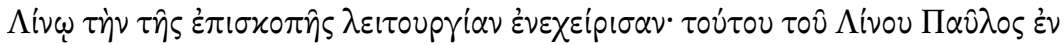

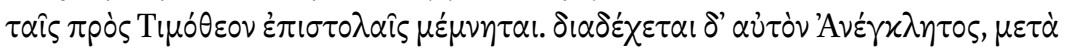

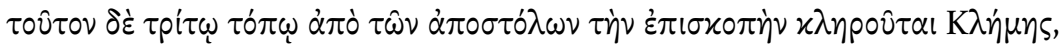

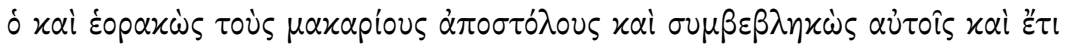

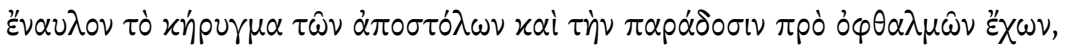

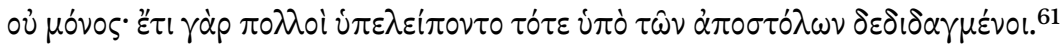

Therefore after the blessed apostles had founded and built the church, they handed the ministry of the office of bishop over to Linus. Paul made mention of this Linus in his Letter to Timothy. Anencletus succeeded him,

59 Praescr. 32.

6o See also Brent (2013) 171.

61 Irenaeus, $A d v$. Haer. 3.3.2, in Eusebius, HE 5.6.1-2. 
and after him in third place Clement obtained the office of bishop from the apostles; he had seen the blessed apostles, had communicated with them, and with the preaching of the apostles still ringing in his ears he held their tradition before his eyes. He was not alone, for at that time there were still many left who had been taught by the apostles.

It appears that already in the second century in a polemical context bishops' lists existed or had been construed, to which both Irenaeus and Tertullian are able to refer. In his list, Irenaeus included both apostles, ${ }^{62}$ while Tertullian singled out Peter alone. As many third century sources show, the latter tradition continues in the West and subsequently elsewhere as well. ${ }^{63}$

For Tertullian, this ecclesiastical tradition was key for truth and legitimacy. He maintains that those who do not follow the rule do not have any rights, not even to use the Christian writings on which they base themselves for their arguments.

Si haec ita se habent, ut ueritas nobis adiudicetur, quicumque in ea regula incedimus quam ecclesiae ab apostolis, apostoli a christo, christus a deo tradidit, constat ratio propositi nostri definientis non esse admittendos haereticos ad ineundam de scripturis prouocationem quos sine scripturis probamus ad scripturas non pertinere. ${ }^{64}$

If this is so that truth is granted to us, every one of us who walks according to this rule, which the churches handed down from the apostles, the apostles from Christ, and Christ from God, then the rationale of our main point is established, defining that heretics should not be allowed to provoke us from the scriptures, since we prove without the scriptures that they have nothing to do with the scriptures.

Ita non christiani nullum ius capiunt christianarum litterarum ad quos merito dicendum est: qui estis? quando et unde uenistis? quid in meo agitis, non mei? quo denique, Marcion, iure siluam meam caedis? qua licentia, Valentine, fontes meos transuertis? qua potestate, Apelles, limites meos commoues?65

62 For the role of Paul in the works of Irenaeus, see Blackwell (2011) 190-206.

63 Giles (1952). Butler (1996). See also Eusebius $H E$ 5.28.3, in which Pope Victor is listed as the thirteenth bishop of Rome after Peter and Zephyrinus.

64 Praescr. 37.

65 Praescr. 37. 
Thus, not being Christians, they have no right to Christian scriptures; one should justly say to them: 'Who are you? When and from where did you come? What do you have to do with me, you who are not mine? Finally, by what right do you, Marcion, cut my wood? By what license, Valentinus, do you divert my streams? By what power, Apelles, do you move my boundaries?'

Ego sum heres apostolorum. Sicut cauerunt testamento suo, sicut fidei commiserunt, sicut adiurauerunt, ita teneo. ${ }^{6} 6$

I am the heir of the apostles. Just as they bequeathed in their will, just as they committed to trust, just as they swore, so I hold possession.

Vos certe exheredauerunt semper et abdicauerunt ut extraneos, ut inimicos.

You they certainly have disinherited forever and renounced as outsiders, as enemies. ${ }^{67}$

Tertullian has nothing but harsh words for his opponents, whom he mentions by name: Marcion, Valentinus, and Apelles; in this he targets followers of these teachers, those who enlisted in their schools and studied their writings. There is a strong sense of "us" against "them" in these texts, "us" standing for the rightful owners of the inheritance, and "them" for those who should not even be allowed to read the sacred writings or to enter a discussion based on the scriptures. The "us" is legitimate, the "them" a total fraud, who should be disinherited and rejected as strangers and enemies of the apostles. There is no ranking of apostles in Tertullian's statements here, and the focus is not only on Peter and Paul, but on all apostles. Both Irenaeus and Tertullian have strong institutional views that stress the founding fathers of the Roman church and the legitimacy of the church's existence. That Paul could not be the founder of the Roman church, as Irenaeus claimed ("the church.... founded and established by the two most glorious apostles Peter and Paul at Rome"), is a detail that is temporarily lost in Irenaeus' polemical fervor - he undoubtedly knew better.

In the same work (De Praescriptione) Tertullian provides additional information with bearing on our subject. He evokes the text of Galatians and blames his opponents for interpreting the disagreement between Peter and Paul in

66 Praescr. 37.

67 Praescr. 37. For a general survey of the traditions of Peter and Paul in North Africa, see Dunn (2001) 405-15. More recently, see the magnificent opus of Burns and Jensen (2014). 
an incorrect and unjustifiable way; they accuse Peter and the other apostles of being ignorant, claiming that their apostolic performance was imperfect. ${ }^{68}$ The accusation is repeated several times in his books Against Marcion with basically the same arguments. ${ }^{69}$

Solent dicere non omnia apostolos scisse, eadem agitati dementia qua susum rursus conuertunt, omnia quidem apostolos scisse sed non omnia omnibus tradidisse, in utroque Christum reprehensioni inicientes qui aut minus instructos aut parum simplices apostolos miserit. ${ }^{70}$

They are accustomed to saying that the apostles did not know everything; driven by the same madness by which they turn (things) upside down again - (saying that) the apostles did indeed know everything but did not hand everything on to everybody, in either case casting the blame on Christ for sending out apostles who were either poorly educated or rather dishonest.

Proponunt ergo ad suggillandam ignorantiam aliquam apostolorum quod Petrus et qui cum eo reprehensi sunt a Paulo. Adeo, inquiunt, aliquid eis defuit, ut ex hoc etiam illud struant potuisse postea pleniorem scientiam superuenire, qualis obuenerit Paulo reprehendenti antecessores. ${ }^{71}$

To scoff at some ignorance of the apostles they propose therefore that Peter and his companions were rebuked by Paul. Thus, they say, something was lacking in them, so as to fabricate from this the idea that afterwards they would be able to arrive at a fuller knowledge, such as came to Paul when he rebuked his predecessors.

Nam et ipsum Petrum ceterosque, columnas apostolatus, a Paulo reprehensos opponunt, quod non recto pede incederent ad euangelii ueritatem, ab illo certe Paulo, qui adhuc in gratia rudis, trepidans denique, ne in uacuum currisset aut curreret, tunc primum cum antecessoribus apostolis conferebat. ${ }^{72}$

68 Praescr. 23.1; 23.5; 24.2. In general, see also Wechsler (1991).

69 Adv. Marc. $1.20 ; 4.2 .5-3.5 ; 5.3 .1-7$.

$70 \quad$ Praescr. 22.

71 Praescr. 23.

72 Adv. Marc. 1.20; see also 4.2.4-3.5; 5.3.1-7. In 4.2.4 Tertullian writes: Nam ex his commentatoribus, quos habemus, Lucam uidetur Marcion elegisse, quem caederet. Porro Lucas non apostolus, sed apostolicus, non magister, sed discipulus, utique magistro minor, certe tanto posterior, quanto posterioris apostoli sectator, Pauli sine dubio, ut et si sub ipsius Pauli 
For they respond that Peter himself and others, pillars of apostleship, were rebuked by Paul for not walking uprightly according to the truth of the gospel, by that very Paul, who still unformed in grace, in short, in fear of having run or running in vain, was then meeting for the first time with the apostles who preceded him.

For his part, Tertullian tries to show that there was no real conflict between the two apostles and gives a full exegetical survey of Paul's texts with additional references to the book of Acts, which - as he claims - his opponents view as a forgery. Tertullian also brings up the idea of antiquity and seniority, arguing that Peter and others were earlier than Paul and that Paul is a latecomer. ${ }^{73} \mathrm{He}$ used the same argument of antiquity in another debate about the authority of the gospels, arguing that Marcion selected and emended the Gospel of Luke as his preferred gospel. ${ }^{74}$ In this discussion, Tertullian portrays Luke as a double latecomer, arguing that he was not even an apostle but an apostolic man (non apostolus sed apostolicus), not a master but a pupil (non magister sed discipulus), and inferior to and later than his master - the master being Paul, who in turn was himself later than others. Thus, this whole discussion centers around who was first as a way to express who was more authentic and/or closer to the truth. As the discussion plays out (and, of course, we only have Tertullian's side of it), ${ }^{75}$ Tertullian vigorously denies that Paul is superior to Peter as his opponents had argued. It is interesting to see how Tertullian firmly defends the position of Peter but without degrading Paul, who is obviously the hero of the opposite party - elsewhere Tertullian had called Paul haereticorum apostolus. ${ }^{76}$

As appears from the first volume of Biblia Patristica, Tertullian is the first Christian writer to seriously engage in this discussion and scrutinize the

nomine euangelium Marcion intulisset, non sufficeret ad fidem singularitas instrumenti destituta patrocinio antecessorum. For from these interpreters whom we have, Marcion seems to have chosen Luke as the one to chop up. Now Luke was not an apostle but an apostolic man, not a master but a pupil, in any case less than his master, certainly so much later, as he was a follower of a later apostle, without doubt Paul, so that even if he (Marcion) had presented his gospel under the name of Paul himself, the single document lacking the protection of predecessors would not have been sufficient for faith.

Centuries later we still can hear the reverberations of this in Augustine's sermons: Beatus Petrus primus apostolorum, beatus Paulus nouissimus apostolorum. See also Van den Hoek and Herrmann (2013) 319 .

74 For the argument of praescriptio novitatis, see Lieu (2015) 62 .

75 For the various presentations of Marcion in Early Christianity, see Lieu (2015).

${ }_{76}$ Adv. Marc. 3.5; see also Irenaeus, Adv. Haer. 4.41.4; and Cooper (2013) 224-46. 
passage from Galatians, apparently driven by arguments of his opponents. ${ }^{77}$ The passage does not seem to have been problematic for writers from the East. We also know that this text continues to be heavily debated in the West, well into post-Constantinian times, as the famous debate between Augustine and Jerome shows. ${ }^{78}$

A similar debate goes with a gospel passage that Tertullian quotes in this context, Mat. 16.18-19:

and I tell you, you are Peter, and on this rock I will build my church, and the gates of Hades shall not prevail against it. I will give you the keys of the kingdom of heaven, and whatever you bind on earth shall be bound in heaven, and whatever you loose on earth shall be loosed in heaven.

As with the passage from Galatians this text does not have much resonance in the East at the time but has great significance in the West.

Quis igitur integrae mentis credere potest aliquid eos ignorasse quos magistros dominus dedit, indiuiduos habens in comitatu in discipulatu in conuictu, quibus obscura quaeque seorsum disserebat, illis dicens datum esse cognoscere arcana quae populo intellegere non liceret? latuit aliquid Petrum, aedificandae ecclesiae petram dictum, claues regni caelorum consecutum et soluendi et alligandi in caelis et in terris potestatem ${ }^{79}$

But who of a sound mind can believe that they whom the Lord gave as teachers were ignorant of anything, keeping them inseparably in his company, in his discipleship, in his community, to whom he used to explain privately whatever was unclear; telling them that it was given to them to get to know secrets that people were not allowed to understand. Was anything concealed from Peter, who was called the rock on which the church would be built, who obtained the keys of the kingdom of heaven and the power of loosing and binding in heaven and on earth?

Tertullian also quotes the Matthean passage in De Pudicitia, a treatise from his later period. ${ }^{80}$ After he joined the movement of the New Prophecy and

77 In a different context, Christoph Markschies calls attention to the conflict of Peter and Paul as a 'central point of departure for all of Marcion's theological thinking'; Markschies (2015) 226.

78 See also Van den Hoek and Herrmann (2013) 317-21, and bibliography.

79 Praescr. 22.4; cf. Monog. 8.4.

8 o Pud. 21. 
openly cut ties with his former church, he changed his views considerably. In this treatise, he employs Matthew's words but this time not against heretical opponents but against the authority of the church and the bishop - it is not certain whether this was the bishop of Rome or more locally of Carthage. At stake are matters of penance and chastity. Tertullian questions the authority of the church to forgive people for sexual misconduct, maintaining that adultery and fornication have their place of "honor" between idolatry and homicide "honor" is used sarcastically, and the whole treatise is filled with bitter sarcasm and harsh ridicule:

De tua nunc sententia quaero, unde hoc ius ecclesiae usurpes. Si quia dixerit Petro dominus: super hanc petram aedificabo ecclesiam meam, tibi dedi claues regni caelestis, uel: quaecumque alligaueris uel solueris in terra, erunt alligata uel soluta in caelis, idcirco praesumis et ad te deriuasse soluendi et alligandi potestatem, id est ad omnem ecclesiam Petri propinquam? Qualis es, euertens atque commutans manifestam domini intentionem personaliter hoc Petro conferentem? super te, inquit, aedificabo ecclesiam meam, et: dabo tibi claues, non ecclesiae, et: quaecumque solueris uel alligaueris, non quae soluerint uel alligauerint. ${ }^{81}$

From your point of view, I now ask, why do you usurp this "right" of the church? If it is because the Lord has said to Peter, 'Upon this rock I will build my church, to you I have given the keys of the kingdom of heaven,' or 'whatever you shall bind or loose on earth, shall be bound and loosed in heaven,' is it for that reason that you presume that the power to loose and tie has transferred to you, that is to every church akin to Peter. What kind of person are you that you subvert and totally change the clear intention of the Lord who bestowed this on Peter personally. 'Upon you, he said, I will build my church,' and 'I will give the key to you,' not to the church, and 'whatever you shall loose or bind,' not what they shall loose or bind.

Some generations later Tertullian's compatriot, Cyprian, will exploit the Matthean text heavily in favor of the position against which Tertullian so fiercely had fulminated. Cyprian asserted that by appointing Peter as the rock upon which the church would be built Christ established the office of the bishop. As successors of Peter, the bishops also became the guarantors of the

$81 \quad$ Pud. 21.9-10. 
unity of the church. ${ }^{82}$ The authority that had been given to Peter first was then shared by all the apostles together, and for Cyprian this became a model for the episcopal college. ${ }^{83}$ Space forbids to go further into the questions of ecclesiastical authority and the passage from Matthew. It is sufficient to note that Paul is nowhere to be seen in this discussion and that all the weight falls on Peter. Tertullian and Cyprian set great store by the Matthean text about Peter and the rock; they exploited it in divergent directions, but both link it to church and authority. ${ }^{84}$

In Rome itself, however, there is only sketchy evidence of the text being employed at this time. The Acts of Peter had referred to it but not to the extent of the North Africans..$^{85}$ In his Dialogue with Trypho Justin Martyr quoted only the preceding doxological part: ${ }^{86}$

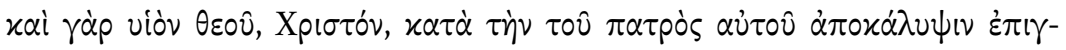

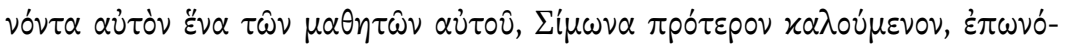
$\mu \alpha \sigma \varepsilon$ Пદ́t

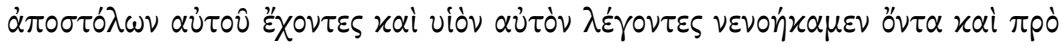

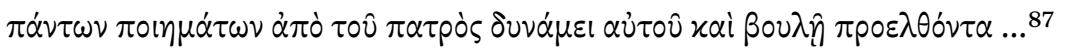

For he (Christ) named one of his disciples - previously called Simon Peter; since he recognized him to be Christ, son of God, according to the revelation of his father: and since we have him recorded in the memoirs

82 As Patout Burns explains: 'the local church consisted of people who were united with their bishop, who symbolized Peter upon whom the church was built'; see Burns and Jensen (2014) 384 .

83 Patout Burns indicates that Cyprian understood Peter 'not only as a figure of the local bishop but as a member of the college of bishops, which Christ had established in choosing the twelve and endowing them with the gift of the holy spirit'. Burns and Jensen (2014) 388 .

84 For the role of the Matthean text in Tertullian, see also Farmer and Kereszty (1990) 80-1.

85 See Acta Petri 7 (Vouaux 276, 2). Si enim me, quem in honore maximo habuit dominus.

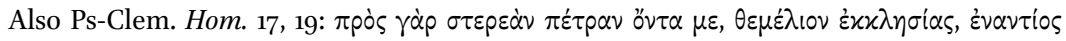
$\dot{\alpha} \nu \theta \dot{\varepsilon} \sigma \tau \eta x \alpha \dot{s} \mu$ ol (For you now stand against me, who is a firm rock, the foundation of the Church).

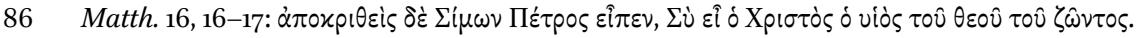

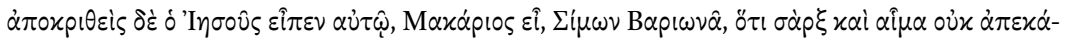

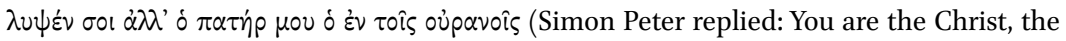
Son of the living God. Jesus replied, blessed are you, Simon Bar Jona, for flesh and blood has not revealed this to you, but my father who is in heaven). For an extensive reflection on the meaning of the Matthean text, see Cullmann (2011) 164-242.

87 Justin Martyr, Dial. 100.4; in Dial. 106.3, in which Justin refers to Peter's name change; see also Tertullian, Adv. Marc. 4.13. 
of his apostles as the Son of God and we call him his Son, we have understood that he is and proceeds before all creatures from the father by his power and will, ...

Interestingly Justin gives full credit to his source here, not as the Gospel of Matthew but as apomnemoneumata: memoirs of the apostles. ${ }^{88}$ As is well known, Justin never mentioned the apostle Paul, and the scholarly debate still goes on about whether or not he knew the letters of Paul. ${ }^{89}$ If he did, then his silence is noticeable, though it is difficult to draw conclusions or make an argument from silence. If Justin did not know about Paul, it is hard to explain that people in his ambiance such as Tatian $\operatorname{did} .{ }^{90}$ At this point we just draw a blanc and only can speculate about the reasons. ${ }^{91}$

\section{Conclusion}

Working my way through these materials, it dawned on me that the image of Peter and Paul as a unity cannot easily be deconstructed based on the sources at hand. By-and-large and very early in the reception history, the two apostles come as a pair. We also saw this phenomenon in real historical and documentary terms in the mid-third century in the intercession graffiti on Via Appia. The intercessions are to Peter and Paul together but with Latin speakers tending to give precedence to Peter and Greek speakers favoring Paul. Eastern sources appear to have named Peter and Paul together in early bishops' lists (see Irenaeus and Dionysius) while Western sources would single out Peter (see Tertullian).

Textual sources also show that in the mid-second century struggles between various groups competing for dominance, there was an attempt to eliminate, or, at least, tone down the importance of Peter in favor of Paul. We can also discern a counter movement in the West, perhaps already in Justin Martyr's position, but this remains highly uncertain. Much more evident is the polemical

88 See also Markschies (2015) 233 .

89 For a recent discussion of Justin Martyr and the use of Paul in connection with Marcion, see Lieu (2015) 418-21.

9o Eusebius remarks that Tatian 'dared to paraphrase some words of the apostle as though

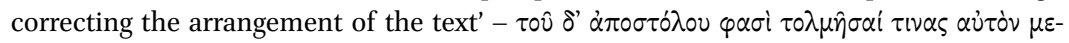

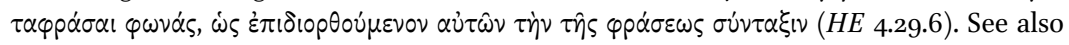
Jerome, Com. ad Titum, praef:: sed Tatianus, Encratitarum patriarches, qui et ipse nonnullas Pauli epistulas repudiauit, hanc uel maxime, hoc est ad Titum, Apostoli pronuntiandam credidit, 'But Tatian, patriarch of the Ebionites, who also himself repudiated some letters of Paul, believed that especially this one, the one to Titus, should be declared of the apostle.'

See also Paul Foster's conclusions; Foster (2011) 124-25. 
reaction of Tertullian, who opposed the idea of Paul's superiority and made vigorous attempts to rescue Peter and Peter's reputation but ... without losing Paul. It is important to realize that these anti-heretical debates equally wanted to preserve the Pauline legacy but not what they perceived as ultra-Pauline tendencies. ${ }^{92}$ I am fully aware that Tertullian's treatises are polemical, acerbic and one-sided, but those are the materials that we mostly have at out disposition.

Tertullian's interpretations of key texts from Galatians and the Gospel of Matthew are reflections of spirited debates; they are glimpses - brief and partial as they may be - into the defense of Peter's position in the West, while these texts do not attract much attention in the East at the time. ${ }^{93}$ We saw a hermeneutical trail of the Matthean logia, already with a faint start in Justin Martyr and the Acts of Peter, and with a strong resonance in the works of Tertullian and Cyprian. For Tertullian, the figure of Peter emerges in both antiheretical polemics and (after breaking ties with the church) in polemics with the church about the exercise of apostolic authority. For Cyprian, these texts no longer form a polemical argument; he developed them fully to defend the institutional church and its hierarchy - with special focus on the position of the bishop and the episcopal college. In this we see a clear elevation of the role of the apostle Peter.

Whether the tendency in the West and, particularly, in Rome to elevate one apostle over the other already existed before the last decades of the second century remains an interesting but unanswered question. The interval between the early second century sources, such as 1 Clement and the later with Justin Martyr, the Acts of Peter and Tertullian remains pretty much open for discussion, and, for lack of evidence, open for speculation, which I happily leave to others.

\section{Acknowledgements}

Thanks go to the organizers of the conference in Amsterdam and to its participants for giving feedback. I am grateful to John Herrmann, Angelo di Berardino, Robin Jensen, and Paolo Liverani for their help and advice. I am greatly indebted to Arnold Provoost for generously sharing his Repertorium with me. Thanks go to my NT friends for lending me a willing ear and allowing me into

$92 \quad$ See also Ferguson (2013) 33 .

93 Patout Burns suggests that a text, such as John 21:18-19, may have had a similar function as the passages from Galatians and Matthew (personal communication). 
their territory: Tjitze Baarda $\uparrow$, Giovanni Bazzana, Eldon Epp, Bert Jan Lietaert Peerbolte (and the Amsterdam New Testament Colloquium), AnneMarie Luijendijk, and Riemer Roukema. Final thanks go to Patout Burns for discussing with me the positions of Tertullian and Cyprian, and to Jan Bremmer for recent bibliography. While going to press, Antonio Felle sent me his very resourceful article of 2012 on the graffiti of the Triclia and also provided me with a recent picture of ICVR, V 12935, EDB 26596; I am most grateful for his speed and collegiality.

\section{Bibliography}

Armstrong, M. 1993. A Thesaurus of Applied Motives on African Red Slip Ware (Ph.D. diss.). New York: New York University.

Baarda, T. 2017. The Diatessaron and Its Beginning:A Two-Fold Statement of Tatian. (still unpublished, sent by the author via email).

Bekker-Nielsen, T. 2002. Nets, Boats and Fishing in the Roman World, $C \& M$ 53, 215-33.

Bisconti, F. 200o. Temi di iconografia paleocristiana, ed. F. Bisconti. Città del Vaticano: Pontificio Istituto di Archeologia Cristiana.

Blackwell, B. 2011. Paul and Irenaeus. In Paul and the Second Century, eds. M. F. Bird and J. R. Dodson. London/New York: T\&T Clark International.

Bockmuehl, M. 1998. The Epistle to the Philippians. Peabody, MA: Hendrickson Publishers.

Bockmuehl, M. 2010. The Remembered Peter: in Ancient Reception and Modern Debate. Tübingen: Mohr Siebeck.

Bockmuehl, M. 2012. Simon Peter in Scripture and Memory: The New Testament Apostle in the Early Church. Grand Rapids, MI: Baker Academic.

Bremmer, J. N. 1998. The Apocryphal Acts of Peter: Magic, Miracles, and Gnosticism, ed. J. N. Bremmer. Leuven: Peeters. Republished and updated in Bremmer (2017).

Bremmer, J. N. 2010. The Pseudo-Clementines, ed. J. N. Bremmer. Leuven: Peeters. Republished and updated in Bremmer (2017).

Bremmer, J. N. 2017. Maidens, Magic and Martyrs in Early Christianity. Collected Essays I. Tübingen: Mohr Siebeck.

Brent, A. 2013. Tertullian and the Role of the Bishop. In Tertullian and Paul, eds. T. D. Still and D. E. Wilhite, 165-86. New York: Bloomsbury-T\&T Clark.

Burns, J. P. and R. M. Jensen. 2014. Christianity in Roman Africa: The Development of its Practices and Beliefs, in collaboration with G. W. Clarke, S. T. Stevens, W. Tabbernee, and M. A. Tilley. Grand Rapids, MI: William B. Eerdmans Publishing Company.

Butler, S. 1996. Jesus, Peter, and the Keys: A Scriptural Handbook on the Papacy, eds. S. Butler, N. Dahlgren, D. Hess. Santa Barbara, CA: Queenship Publishing Co. 
Carandini, A. 2013. Su questa pietra. Gesù, Pietro e la nascita della Chiesa. Roma: Laterza. Cooper, K. 2013. Communis Magister Paulus: Altercation over the Gospel in Tertullian's Against Marcion. In Tertullian and Paul, eds. T. D. Still and D. E. Wilhite, 224-46. New York, NY: Bloomsbury-T\&T Clark.

Cullmann, O. 2011. Peter: Disciple, Apostle, Martyr (with a new introduction by H. K. Bond). Waco, TX: Baylor University Press.

Di Berardino, A. 2015. Roman Tradition on Paul's Death: Literary and Archaeological Data, In The Last Years of Paul: Essays from the Tarragona Conference, June 2013, eds. A. Puig i Tàrrech, J. M. G. Barclay, J. Frey, and O. McFarland, 521-32. Tübingen: Mohr Siebeck.

Dijkstra, R. 2016. The Apostles in Early Christian Art and Poetry. Leiden/Boston: Brill.

Dresken-Weiland, J. 2011. Petrusdarstellungen und ihre Bedeutung in der frühchristlichen Kunst. In Petrus und Paulus in Rom: eine interdiszipliäre Debatte, eds. S. Heid, R. von Haehling, V. M. Strocka, and M. Vielberg, 126-52. Freiburg: Herder.

Dresken-Weiland, J. 2o11a. Bilder im Grab und ihre Bedeutung im Kontext der Christianisierung der frühchristlichen Welt, Antiquité Tardive 19: 63-78.

Dunn, G. D. 2001. Peter and Paul in Rome: The Perspective of the North African Church, In Pietro e Paolo: il loro rapporto con Roma nelle testimonianze antiche (XXIX Incontro di studiosi dell'antichità cristiana, Roma, 4-6 maggio 2000), 405-15. Roma: Institutum Patristicum Augustinianum.

Eastman, D. L. 2011. Paul the Martyr: The Cult of the Apostle in the Latin West. Atlanta: Society of Biblical Literature.

Epigraphic Database Bari (EDB), Inscriptions by Christians in Rome (3rd-8th century $C E)$ : http://www.edb.uniba.it/.

Farmer, W. R. \& R. Kereszty. 1990. Peter and Paul in the Church of Rome: The Ecumenical Potential of a Forgotten Perspective. New York: Paulist Press.

Felle, A. E. 2012. Alle origini del fenomeno devozionale cristiano in Occidente. Le inscriptiones parietariae ad memoriam Apostolorum, In Martiri, Santi, Patroni: per una archeologia della devozione, eds. A. Coscarella and P. De Santis (Atti X Congresso Nazionale di Cristiana, Calabria, 2010), 477-502. Calabria: Università della Calabria.

Ferguson, E. 2013. Tertullian, Scripture, Rule of Faith, and Paul, In Tertullian and Paul, eds. T. D. Still and D. E. Wilhite, 22-33. New York, NY: Bloomsbury-T\&T Clark.

Foster, P. 2011. Justin and Paul, In Paul and the Second Century, eds. M. F. Bird and J. R. Dodson, 124-25. London/New York: T\&T Clark International.

Foster, P. 2015. Peter in Noncanonical Traditions. In Peter in Early Christianity, eds. H. K. Bond and L. W. Hurtado, 222-62. Grand Rapids, Michigan: William B. Eerdmans Publishing Company.

Gahbauer, F. 2001. Petrus und Paulus in Rom: Sprachlich und ekklesiologisch bedingte Tendenzen zugunsten des Petrus oder Paulus in den Texten (2.-4. Jh,)? In Pietro e Paolo: il loro rapporto con Roma nelle testimonianze antiche (XXIX Incontro di 
studiosi dell'antichità cristiana, Roma, 4-6 maggio 2000), 155-67. Roma: Institutum Patristicum Augustinianum.

Giles, E. 1952. Documents Illustrating Papal Authority AD 96-454. London: SPCK, reprinted in 1979 by Hyperion Press.

Gnilka, J. 2002. Petrus und Rom: Das Petrusbild in den ersten zwei Jahrhunderten. Freiburg: Herder.

Gray, P. 2016. Paul as a Problem in History and Culture: The Apostle and his Critics through the Centuries. Grand Rapids, MI: Baker Academic.

Jensen, R. M. 1992. Moses Imagery in Jewish and Christian Art, SBLSP 31: 395-98.

Jensen, R. M. 2019. Moses and the Christian 'New Moses' in Early Christian Funerary Art. In The Christian Moses: From Philo to the Qur'an, eds. P. Rousseau and J. A. Timbie. Washington D. C.: Catholic University Press.

Koester, H. 1980. History and Literature of Early Christianity. Introduction to the New Testament, vol. 2. New York, Berlin: Walter de Gruyter.

Krautheimer, R. 1965/1975. Early Christian and Byzantine Architecture. Harmondsworth: Pelican History of Art.

Lampe, P. 2003. From Paul to Valentinus: Christians at Rome in the First Two Centuries, eds. M. D. Johnson, M. G. Steinhauser. Minneapolis: Fortress Press.

Lampe, P. 2015. Traces of Peter Veneration in Roman Archaeology. In Peter in Early Christianity, eds. H. K. Bond and L. W. Hurtado, 273-317. Grand Rapids, MI: Eerdmans.

Lampe, P., H. G. Thümmel, and M. Hardt. 2011. Peter (the Disciple). In: Religion Past and Present. Consulted online on 07 October $2017<\mathrm{http}$ ://dx.doi.org.ezp-prodi.hul .harvard.edu/10.1163/1877-5888_rpp_COM_024342>.

Laubscher, H. P. 1982. Fischer und Landleute: Studien zur hellenistischen Genreplastik. Mainz am Rhein: von Zabern.

Lieu, J. M. 2015. Marcion and the Making of a Heretic: God and Scripture in the Second Century. New York, NY: Cambridge University Press.

Lipsius-Bonnet, 1891-1903. Acta Apostolorum Apocrypha, post Constantinum Tischendorf; denuo ediderunt Ricardus Adelbertus Lipsius et Maximilianus Bonnet. Lipsiae: Apud Hermannum Mendelssohn.

Luedemann, G. 1989. Opposition to Paul in Jewish Christianity. Minneapolis: Fortress Press.

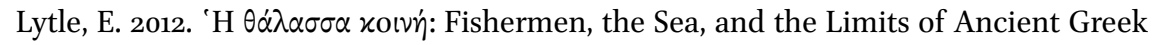
Regulatory Reach, Classical Antiquity 31, 1-55.

Marguerat, D. 2015. On Why Luke Remains Silent about Paul's End (Acts 28.16-31). In The Last Years of Paul: Essays from the Tarragona Conference, June 2013, eds. A. Puig i Tàrrech, J. M. G. Barclay, J. Frey, and O. McFarland, 305-32. Tübingen: Mohr Siebeck. Marichal, R. 1954. L’Année Épigraphique 1954 (1955): no. 54. 
Markschies, C. 2015. Christian Theology and Its Institutions in the Early Roman Empire: Prolegomena to a History of Early Christian Theology. Waco: Baylor University Press.

Paschke, F. 1965-1994. Die Pseudoklementinen II. Rekognitionen in Rufins Übersetzung, 1965, ed. F. Paschke; 1994² ed. G. Strecker. Berlin: Akademie Verlag.

Porter, S. 2005. Paul and his Opponents (Pauline Studies, vol. 2), ed. S. Porter. Leiden/ Boston: Brill.

Provoost, A. 2011. De vroegchristelijke funeraire beeldtaal: met chronologisch repertorium van de catacombenschilderingen in Rome en van de vroegchristelijke sarcofagen, parts 1-3. https://lirias.kuleuven.be/handle/123456789/29629o.

Rehm, B. 1953-1992. Die Pseudoklementinen I. Homilien, 1953, ed. J. Irmscher; $1967^{2}$, ed. F. Paschke; $1992^{3}$, ed. G. Strecker.

Sessa, K. 2012. The Formation of Papal Authority in Late Antique Italy: Roman Bishops and the Domestic Sphere. Cambridge, New York: Cambridge University Press.

Still, T. 2015. Images of Peter in the Apostolic Fathers. In Peter in Early Christianity, eds. H. K. Bond and L. W. Hurtado. Grand Rapids, MI: William B. Eerdmans Publishing.

Snyder, G. F. 1985. Ante Pacem. ArchaeologicalEvidence of Church Life Before Constantine, Macon, GA: Mercer.

Styger, P. 1918. Il monumento apostolico della Via Appia (Diss. Pontificia Accademia di archeologia 13). Città del Vaticano: Pontificia Accademia di archeologia.

Thomas, C. M. 2003. The Acts of Peter, Gospel Literature, and the Ancient Novel:Rewriting the Past. Oxford/New York: Oxford University Press.

Toynbee J. \& J. Ward Perkins, 1956. The Shrine of St. Peter and the Vatican Excavations. London/New York: Longmans, Green.

Van den Hoek, A. \& J.J.Herrmann Jr., 2013. Pottery, Pavements, and Paradise:Iconographic and Textual Studies on Late Antiquity (Supplements to Vigiliae Christianae, vol. 122). Leiden/Boston: Brill.

Van den Hoek, A. 2017. Divine Twins or Saintly Twins: The Dioscuri in an Early Christian Context. In Gods, Objects, and Ritual Practice (Studies in Ancient Mediterranean Religions, ed. S. Blakely), 17-51. Atlanta: Lockwood Press.

Van den Hoek, A. \& C. Mondésert. 2001. Clément d'Alexandrie. Les Stromates. Stromate IV. Introduction, texte grec et notes par A. van den Hoek, traduction de C. Mondésert (SC 463). Paris: Les éditions du Cerf.

Vouaux, L. 1922. Les actes de Pierre, Paris: Letouzey \& Ané.

Wechsler, A. 1991. Geschichtsbild und Apostelstreit: eine forschungsgeschichtliche und exegetische Studie über den antiochenischen Zwischenfall (Gal 2, 11-14). Berlin/New York: Walter de Gruyter.

Zwierlein, O. 2010. Petrus in Rom: die literarischen Zeugnisse. Mit einer kritischen Edition der Martyrien des Petrus und Paulus auf neuer handschriftlicher Grundlage. Berlin/ New York: Walter de Gruyter. 
Zwierlein, O. 2011. Petrus in Rom? Die literarische Zeugnisse. In Petrus und Paulus in Rom: eine interdiszipliäre Debatte, eds. S. Heid, R. von Haehling, V. M. Strocka, and M. Vielberg, 444-67. Freiburg: Herder.

Zwierlein, O. 2013. Petrus und Paulus in Jerusalem und Rom: vom Neuen Testament zu den apokryphen Apostelakten, ed. O. Zwierlein. Berlin: Walter de Gruyter. 